\title{
QUO VADIT PSYCHOLOGIA: A PHILOSOPHIA VEL AD PHILOSOPHIAM?²
}

\begin{abstract}
САЖЕТАК. Куда иде психологија: од филозофије или ка филозофији? Чини се да је и сама психологија већ морала да тематизује, између осталог, и последице и домете своје „сепарације и индивидуације од филозофије и својих филозофских извора. Уместо филозофског контекста, у коме су ранија психолошка сазнања обитавала, данашња психологија зарад своје изградње као емпиријске науке, тј. величања основних постулата науке у домену научног метода, метода позитивне науке, препуштена је метафизици, метатехници и математизацији, чиме је изгубила и своју „душу”, и душу као властити предмет проучавања. Њено избегавање да помене реч „душа” можда најбоље говори о томе. Данашња психологија је - као суштински антифилозофска психологија - сместила 'психичко' у физичке, оториноларинголошке или офталмолошке садржаје, истражујући углавном једноставне емпиријске односе. Таква психологија иде против сопствених интереса управо стога што њена антифилозофска оријентација своди њен предмет на физичку чињеницу спремну да уђе искључиво у математичке операције. Насупрот томе, психологија која би одржавала везу с филозофијом и сама би се постављала као искуство, а не као теоријско схватање. Уместо да предмет психологије буде сам живот, како је сугерисао Хајдегер (Heidegger), а не тек осети, утисци на темељу опипа и учинци памћења, дешава се управо супротно. Када би психологија испитивала живот у његовој потпуној стварности, од ње се свакако не би тражило да буде права филозофија, већ би филозофски приступ само доприносио да психолошко
\end{abstract}

misotodorovic@yahoo.com

2 Рад је примљен 19. маја 2015, а прихваћен за објављивање на састанку Редакције 3ठорника одржаном 22. јула 2015. 
истраживање буде критичкије и потпуније. Начин на који се у академској психологији схватају и појединачне функције и сам субјект - добар је показатељ тих „парцијалних” објеката сазнања. Они пак - као парцијалне перспективе психолошких знања - неминовно воде мноштву психологијаิ. Једино филозофија може да представља онај заједнички именитељ у коме је садржана потреба за стварањем јединствене науке која не подразумева да се Мноштво сведе на Једно, већ подразумева непостојање таквих теоријских 'испада' предрасуда̄ према појмовима „ментални ентитети” и „психички процеси” какве је бихевиоризам оставио у наслеђе. Ако Жил Делез (Gilles Deleuze) и Феликс Гатари (Félix Guattari) могу да поставе питање шта је филозофија, могли би и психолози себи да поставе исто питање. Тим пре што би од филозофије „као вештине формирања, изумевања, произвођења појмова" (по науку Делеза и Гатарија, међу осталима) могли да имају велику помоћ.

КљУЧНЕ РЕЧИ: антифилозофска психологија, егзистенцијалистичка филозофија, егзистенцијалистичка психотерапија, смисао бивствовања, расцепљени субјект, жеља.

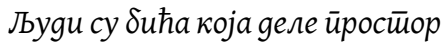
о коме физика нишита не зна...

Crō̄epgujк

Човек и 'психичко' као најексклузивнији објект науке - каквим их је сматрао Карл Густав Јунг (Carl Gustav Jung) - не би то били када ठи били лако доступни научном, односно психолошком изучавању. Ексклузивност објекта психологије, најкраће речено, чини његова тајновитост и смештеност у загонетке. Тамо где се 'психичко' види као нешто једноставно, прозирно, или као доступно, ту сигурно не станује право 'психичко' нити 'психичко' динамске психологије. Интерес многих за психологију побуђује управо то што у њој нема једноставних, лако доступних одгово-

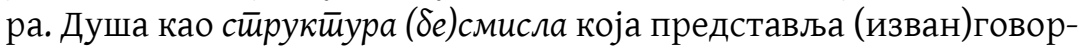
не везе између говорних бића мора већ по себи бити огромна загонетка. Језик као господар човека, управо зато што конституише његову личност и његову судбину, како каже Сартр (Sartre, 1979, str. 63), не може бити нешто лако разумљиво. Психологија (мањевише у целини, мада би се посебно могла издвојити бихевиорална) олако прелази преко увида Емила Сиорана (Emil Cioran) да је човек - језик, ван кога све постаје магловито и нестварно (Cioran, 2010, str. 125). За данашњу академску психологију, склону позитивизму у подручју које апсолутно није погодно за такав при- 
ступ, о свему се може више говорити него о неком тајновитом подручју или загонеткама. У њој постављене хипотезе треба математизовати (квантификовати) и већ на основу података из анкете истина о души биће ту. Но, то је можда истина тих и таквих хипотеза, али сигурно није и истина душе. У настојању да покаже шйа је човек, психологија се, сасвим разумљиво, морала кретати споро и деловала је, како је Јасперс (Karl Jaspers) говорио, као конструкција метафизичких принципа, која је давала схему елемената или снага̂ душе (Jaspers, 1987, str. 119). То што је она сам живот покушала да схвати на основу онога што га сачињава најчешће ју је остављало без разумевања унутрашњих веза сазнатих делова. Емпиријски приступ, којим се психологија поносила и који ју је највише разликовао од филозофије којој је припадала, неретко је ठио, како каже Јасперс, испитивање бескрајног материјала из године у годину и изношење, у основи, једног истог (Jaspers, 1987, str. 120).

„Распарчана и нашироко описана у хиљаду неважних, ништавних појединости експерименталног рада, она је, коначно, била још само маска науке" (Jaspers, 1987, str. 119).

Експериментални приступ који доминира позитивном науком није никако једини пут којим психологија нужно мора ићи - због саме природе 'психичког' - која се на том путу тешко може срести. Оно што остаје изван експерименталног оквира управо и доводи до тога да наука, како каже Брус Финк (Bruce Fink), „зашива” и „пришива” субјект, који је занемарила, односно искључила из свог подручја (Fink, 2009, str. 158). О томе је Лакан прецизно говорио у свом раду Наука и исӣина (Lacan 1974). Колико год то некима изгледало чудно, психологија је нову дубину показала управо у филозофском контексту, као средство промишљања у филозофији егзистенције код Кјеркегора (Kierkegaard) и Ничеа (Nietzsche), када је покушавала да види све потенције и границе људског бивства.

Колики је утицај филозофије на разумевање 'психичког' и поготово на изградњу психолошког сйила неопходног за динамичко сагледавање 'психичког', можда би најбоље могло да се види у целокупном психотерапијском приступу стога што он полази не само од тога да исйина ослобађа већ и да нема ничег другог осим истине што може да нас ослободи. Где и у чему различите психотерапијске школе виде истину, како до ње долазе и саопштавају је пацијенту, с циљем да и он покуша да се у њу смести, сасвим је друго питање. Чак онда када је виде на другачијим местима и ка- 
да је 'избављају' на различите начине, морају поћи од заједничке основе која се састоји у томе да су поруке људске душе, било свесне било несвесне, у ономе битном, суштинском увек исте. Лако је видети како различити теоријски и на њима засновани психотерапијски језици употребљавају конструкте из истог регистра. Проблем је у томе што психологија и поготово психијатрија не

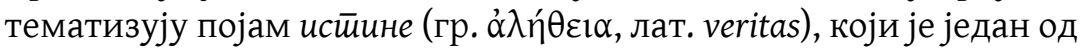
темељних појмова филозофије. Колико је то крупно питање и за саму филозофију, може се видети из различитих схватања током историје филозофије, у којој је исӣина слагање мисли и ствари, слагање суда с оним о чему се суди а што је такво какво јесте, без обзира на то како ми о томе судимо, слагање представе с предметом (по теорији кореспонденције), слагање мисли једних с другима, односно са стварношћу (Кант [Kant]), слагање с човековим потребама, односно практична корисност њиховог задовољења (Џејмз [James] и Дјуи [Dewey]), оно што је биолошки корисно (Ниче), или „систематска кохерентност” карактеристична за целину (према теорији кохеренције), или пак бивствовање у својој несакривености (Јасперс, Хајдегер). Полазећи од картезијанског субјекта као јединства бивствовања и мишљења, психологија може инсистирати једино на истини у субјективном смислу. Тек од филозофски веома образованог психоаналитичара Жака Лакана, или од филозофа Доналда Дејвидсона (Donald Davidson), психологија је могла сазнати да је истиина смештена у узроку. Уважа-

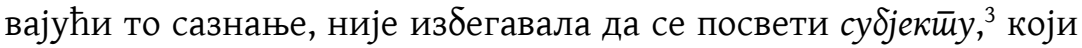
произлази управо из тог узрока. Да ли је без таквог појмовног разграничења, коме психологија није баш превише вична, могуће разумети драму која се одвијала у Шенбурском парку, где се Фројдов Човек ӣaц̧ов вртео у кругу ирационалног понашања само зато да не би био у подручју рационалног?

За разлику од оваквог пропитивања појма истине, почев од тога шта је истина, постоји ли једна или више истина, да ли је она субјективна или објективна, апсолутна или релативна, апстрактна или конкретна, вечна или пролазна, психологија (нарочито академска) својим крајње редукционистичким приступом своди истину на неку врсту вредности. Како је могуће да су психоаналитичке, ठихевиоралне или когнитивистичке истине о истом 'психичком' тако различите, а некад и међусобно искључиве? Управо зато што не постоји нешто што би се могло сматрати „узроком”. Чини се да је немогуће да психологија промишља категорију „узрока” изван филозофије све и да конкретно долази до 
места „узрока” и да га „схвата” или схвата у истини конкретног психичког.

Посматрајући многа експериментална истраживања, нарочито она која припадају академском дискурсу, а пре свега експериментална истраживања изложена у магистарским и докторским радњама, у којима догађаји одвећ лако воде другим догађајима све у складу с добро познатим „законима”, није тешко увидети како нестаје онај за науку најзначајнији процеп између узрока и последице. Такав „научни” приступ све више и више уклања садржај из појма „узрока”, доводећи у сумњу да психологија може да покаже шта је човек. Могло би се рећи да остварење мисије психологије зависи од тога колико је испуњава категорија „узрока”. Уколико наука о души не полази од узрока као оног што ремети глатко функционисање законоликих интеракција, како је говорио Лакан (Fink, 2009, str. 158), она тешко може нешто рећи и о самим менталним догађајима као што су опажања, осећања, одлучивања и поступци. Без упозорења које долази од филозофије, нема увида да се сви ти догађаји не само опиру уласку у но-

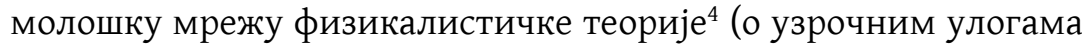
које ментални догађаји имају у физичком свету) него и да узрочни детерминизам мора бити измирен са слободом (слободним

3 Да Жак Лакан није логички и филозофски осмислио појам субјекіиа у оквиру своје теорије ознаке, трансформишући субјект свести у субјект несвесног, науке и жеље, ни данас у психологији не би постојао овакав појам субјекта стога што у њој не постоји опште прихваћен несвесни део психе. И даље би задржао своје филозофске темеље постављене од Ренеа Декарта (René Descartes), Имануела Канта и Едмунда Хусерла (Edmund Husserl), на основу којих се дефинише као сам човек у мери у којој је извор својих мисли и радњи које чини. Смисао појма субјекта у психоанализи (који је, као што је још Фројд [Freud] рекао, омогућила филозофија) јесте да истакне (опет, још од Фројда

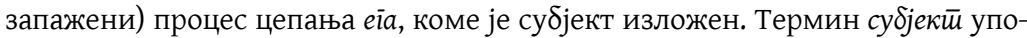
требљава се да означи ठило појединца који је истовремено посматрач других и објект посматрања, било појединца као инстанцу на коју се односи неки предикат или неки атрибут. Из тог разлога (о чему може да сведочи само психоаналитичар који се непосредно ठави самим субјектом) јасно је колико субјект не представља једноставан феномен, као што то најчешће изгледа у експерименталним налазима које математика привидно чини прозирним. Довољно је само рећи да се субјект не може једноставно идентификовати с говорником или личном заменицом у реченици па да се схвати све ограничење математизације. Без појма субјекйа и онога што Лакан зове те́connaissances, тешко је тематизовати статус структуре. За психолога је у пракси од централног значаја питање: Где је субјект? Пронаћи субјект као изгубљени објект јесте циљ praxis-a, праксе сваког психоаналитичара.

4 Природне науке су номотетске (gr. nomothetikos - законодавствени). 
поступањем), како је говорио Доналд Дејвидсон (Davidson, 1995, str. 207). Филозофија мора да претпостави, говорио је Кант, да нема никакве праве противуречности између слободе и природне нужности истих људских радњи, јер људска радња не може да напусти појам природе исто као ни појам слободе (Kant 1981, str. 110). За позитивну науку, у коју психологија жели да се смести, то је и данас јерес.

Ознаке „истинито” и „неистинито”, на које би наука требало да се ослања, немају независну ваљаност по себи, већ само унутар подручја одређеног том науком, на шта упозорава филозофија а што позитивна наука неће да зна. „Истинито” и „неистинито" као бинарне супротности имају своју улогу само, искључиво у том посебном, специфичном контексту. Психологија би, ако ни због чега другог, оно због специфичности свог предмета истраживања - због душе - морала да да̂ предност ономе што доводи у питање самопотврђујућу природу својих властитих аксиома по-

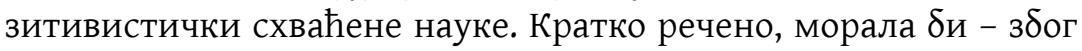
душе - да уважи и узме у обзир оно што не функционише, оно немогуће, оно Лаканово реално ${ }^{5}$, ठез кога је немогуће разумети подручје тежих психичких ломова (траума) и психоза. Тек тада би се могло рећи да се психологија као наука не бави свесним картезијанским субјектом, субјектом који је господар својих властитих мисли и чије је мишљење корелативно његовом постојању.

Шири контекст од кога полазе и психологија и филозофија, а који се у великој мери може сматрати скоро истим, такође је изузетно значајан. У Јасперсовој филозофији јасно видимо да се као њен основни задатак увек у први план ставља човек појединац који у комуникацији, филозофским осветљавањем егзистенције и властите делатности ӣocūaje самостална, слободна егзистенција у односу према трансценденцији. Сви други задаци филозофије: остваривање и уважавање ума насупрот пуком разуму, осветљавање смисла свих наука и целокупног човековог постојања, разјашњавање односа између филозофије и науке, трагање за извориштима филозофије - имају значаја само уколико су обухваћени оним основним задатком, који је и првенствени задатак психологије. Психологија изградњу личности схвата као генезу, пролазак кроз различите фазе у којима однос генезе и структуре указује на то да ли је интеграција у складу с нормом или није, стварајући тако (психотерапијске) стратегије за разумевање „искакања из норме” у случајевима значајнијих одступања која субјекту доносе немалу патњу. Сви други посебни задаци психо- 
логије имају значаја само уколико су обухваћени тим магистралним „задатком”. Освейљавање, комуникацијом, властите егзистенције као историје властитог битка и gостиизање слободе y

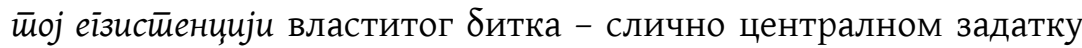
филозофије - јесте истовремено и прецизно дефинисана филозофија свих облика психотерапије као, без сумње, најзначајније области психологије.

Када се психологија не би губила у безбројним варијацијама појединачних варијабли, њен смисао, значај и задатак били би (попут оних у филозофији): прецизно постулирање свих услова који доприносе или не доприносе да се постане интегрисан или (у филозофији би рекли) прави човек. Психологија је апсолутно заинтересована да човек достигне самог себе, свој властити битак, да би се тако ослободио сваке дефинитивне везаности за све оно што се супротставља његовој потреби за трансценденцијом, захваљујући којој и стиче своју меру. Тај циљ психологије требало би да се најјасније види у психотерапији, јер се ту сва одсту-

\footnotetext{
Значење термина реално Лакан је истовремено преузео и из филозофског речника и из Фројдовог концепта психичке реалности да би означио појавну реалност, којој је иманентно представљање и коју је немогуће симболички приказати. Та реалност (Реално) својствена психози (суманутости, халуцинацијама), која је састављена од искључених (одбачених) ознака симболичког, иако апсолутно неприступачна било каквом методу природне науке, јесте од највећег могућег значаја за психологију. Не треба заборавити да су термин реално прво употребљавали филозофи као синоним онтолошког апсолута, ठића по сеठи које измиче перцепцији. Ту праксу психологија (схваћена као строго позитивистичка наука) уопште није следила, иначе ठи томе што је производ човекове унутрашњости (тј. човекова психичка реалност) дала место општеважеће психичке чињенице. објекти чије постојање не зависи од перцепције и који се разликују од објеката које је створила (позитивистичка) наука, упркос разликама, јесу слични. Лакан је у то реално поставио психичку реалност (несвесну жељу и фантазме), али и један „остатак": реалност у којој се испољава жеља, која је неприступачна за сваку субјективну мисао. У психоанализу, али нужно и у целу динамску психологију, појам реалноі дошао је из филозофије и Батајевог (Georges Bataille) појма „хетерологије" (науке о неповратном или непродуктивном - отпатку, измету, ђубрету), једном речју, из појма „другачијег постојања”, онога искљученог из свих норми. Немати тај искључени или, како би Батај рекао, проклети део (Bataille, 1995, str. 36), тј. не укључити га у психолошко истраживање, значи осудити такво психолошко истраживање на партикуларност и недоспевање до истине. У Семинару о еіу из 1954-1955. Лакан истиче да је реално узрок и извор на којем је утемељена сумња неопходна науци. Не долази субјект него сумња, каже Лакан, до неког открића, јер је свако откриће израз кретања у коме се мешају заблуда и истина (Tugendhat, 1990, str. 875).
} 
пања и застрањења виде као шанса да се достигне слобода с оне стране самообмане, као што смо истакли на другом месту (Тодоровић 2015 , стр. 401). Колико се тај циљ остварује у различитим психотерапијским техникама које се ठазирају на различитим психолошким теоријама, зависи од саме теорије.

Достизање самога себе рефлексијом у комуникацији, као пут и начин остваривања човекове могуће егзистенције - за шта се залаже свака психотерапија - јесте нешто што је иманентно самој егзистенцији. Додуше, овакво осветљавање схваћено само као апел егзистенцији, као знак који јој се даје, или као шифра за њу, на основу које се она може дешифровати, тумачити, разумети, упутити, срећемо јасно истакнуто као метод, методичко и методолошко начело само у егзистенцијалистичкој психотерапији. У неким другим облицима терапије ово осветљавање се узима

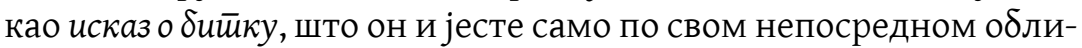
ку, а заправо је ништа друго до злоупотреба. Филозофија упућује психологију да се човек не може мењати споља, како то раде васпитање и образовање, али и терапије у којима је терапеут „онај који зна" и који нуди готову истину о пацијенту, већ да се човек може мењати само изнутра, из себе самог. Треба ли рећи да оно прво ипак (покушавају да) раде све психотерапије изузев психоаналитичке? Тек промена постигнута изнутра, из човека и пацијента самог, комуникацијом ठез настојања да му пружи лажну испуњеност, односно целовитост, која му по природи није дата, јесте она промена којој психологија (као и филозофија) треба да стреми. Испуњеност и целовитост човековог живота не постиже се, поуздано се може рећи, никаквим свезнањем, односно знањем до кога човек долази сам или које му неко даје, примерице и у лику „терапеута”. Испуњеност човека је могућа само као историјска егзистенција слободе и властитог битка појединца у комуникацији.

Будући да је егзистенцијалистичка психотерапија директна примена филозофије егзистенцијализма ${ }^{6}$ на клиничку датост, то сваком говору о овом облику терапијског чињења треба да претходи упознавање с филозофијом која у центар истраживања ставља йосӣојање, односно егзистенцију (лат. existentia). Назив еізиcӣенц̧ија, како каже Хана Арент (Hannah Arendt), не означава ништа више од човековог $\delta и в с \overline{ш в о в а њ а, ~ н е з а в и с н о ~ о д ~ с в и х ~ к в а л и-~}$

6 Прецизно одређујући, филозофије које се ठаве егзистенцијом могу се поделити на: 1) филозофију егзистенције у ужем смислу, 2) егзистенцијалну филозофију и 3) егзистенцијализам. 
тета и обдарености појединца, који се психолошки могу истражити (Arendt, 2013, str. 5). Тиме се заправо хоће да се истакне оно јесиее, које је различито од сушйине, есенције (essentia, esse), онога што чини стабилну суштину неке ствари, темељ њене одређености и посебности. За разлику од есенције, која се односи на то uй $а$ је нешто, егзистенција пак као бивствовање, опстанак обележава да нешто јесие $e$.

Слободно можемо рећи да због недопустиво недовољног познавања филозофије унутар академске психологије и поготово психијатрије, из којих се „регрутују” и егзистенцијални психотерапеути, можда је упутно дубље ући у основне појмове важне за разумевање егзистенцијалне филозофије и њеног значаја за психологију. Треба пре свега истаћи да ,јестее”, односно „бити” означава „ठитак” те да питати „Шта 'јестие??” значи поставити питање о битку. Битак није нека „ствар” и није доступан чулима. О њему се дознаје одговорима на питање: Које је значење (смисао) битка? Филозофија Мартина Хајдегера, као најзначајнијег представника тзв. егзистенцијалне филозофије, незаобилазна је у потрази за тим одговорима. Целокупно његово филозофирање посвећено је питању о битку, па је испитивање егзистенције у њеној временитости, то јест испитивање људског опстанка (Dasein) - само припремање за питање о битку самом. ${ }^{7}$ Смисао за оно што је битак може се истински пробудити само ако се човекова бит промисли као „ek-sistencia” (ex sistentia = из ступања, из постављања, из смештања), то јест као примарна отвореност битка према својој истини, месту ठорављења, кући битка. Употребљавајући термин ту-бивствовање - што је Хајдегеров термин за бивствовање - човека је разложио на низ модуса бивствовања који се феноменолошки могу показати. Будући да се човек појављује у томе да јеč̄e то што јесте, онда он и није нешто више од својих модуса ठивствовања или функција у свету.

Ту бивствовање није једноставно јесиее, него му је у свом бивствовању сийало gо самої свої бивствовања. ${ }^{8}$ Та основна структура од које полази егзистенцијална психотерапија зове се „брига”, која је у основи сваког душевног збивања. Бивствовање о којем се тубивствовање брине јесте „егзистенција” која је непрестано

7 Покушавајући да одговори на то шта значи бити човек, Хајдегер је увео термин Dasein који се поклапа с оним што се обично зове „људско биће”. „Dasein... То ठиће које у свом ठитку познајемо као људски живот; то ठиће у осеठујности свог ठитка, ठиће које јест свако од нас, које свако од нас налази у темељном исказу: ја јесам" (Heidegger, 2005, str. 51). 
угрожена смрћу и напослетку осуђена на пропаст (Arendt, 2013, str. 26). Бивствовање човека је разумљиво бивствовање-у-свету, а оно до чега је том бивствовању стало јесте да се у њему одржи. Како је човеку управо то доведено у питање, то је основни начин ठивствовања-у-свету угрожен до језовитости због уливања страха, с једне стране, и ठезавичајности, с друге. У страху, који је начелни страх од смрти, испољава се оно не-бити-код куће у свету. Као ठивствовање-у-свету човек није створио себе самог, није постао сопство, него је у то своје тубивствовање „бачен”.

Основна теза главног представника филозофије егзистенције Карла Јасперса јесте да се егзистенција као остваривање вечног у времену не може мислити (односно предметно сазнати), него само „позвати” у своју стварност, која је увек „сустајање” (напоредо ступање) пред неизрецивим. Тај однос између постојања и сазнавања указује да бивствовање и мишљење нису исто, чиме је разбијено јединство есенције и егзистенције, изражено ставом да све што се може мислити егзистира и да све што егзистира, већ због своје сазнатљивости, такође мора бити умно (Arendt, 2013, str. 12). ${ }^{9}$ То што човек стално јесте - као део свеобухватног сапостојања - никако не значи да он себе сазнаје свеобухватно. Он сазнаје, како Јасперс каже, само одређене емпиријске облике стварности, попут материје, живота, душе, и то, дакле, емпиријске облике који се не могу свести на једну једину основу (Jaspers, 2000 , str. 37), што и чини да је човек у свом најдубљем ठићу расцейљен (Jaspers, 1987, str. 114). То исто, наиме, да нема људског ठивства ठез расцепа који се мора превазилазити - налазимо и у расцейљеном субјекӣу као једном од централних Лаканових топоса. Начин на који субјект превладава тај расцеп јесте начин на који он овладава собом. ${ }^{10}$

8 Питање $\delta$ ивсиввовања као темељно питање филозофије први је поставио Парменид. Али, тек код Аристотела на почетку Мет̄афизике (Aristotel, 1971, str. 7) ово питање се уводи као темељно питање филозофије у склопу промишљања саме речи филозофија. За психологију је од sophia-е као муgросӣи много значајније оно друго одређење које упућује на изузетан, највиши начин знања, односно питања. Отуда је природно да се као филозофија означи оно знање које у највећој мери има особине које су за знање уопште конститутивне. А конститутивно је за знање, како каже Ернст Тугендхат, да је опште и да за оно што зна може понудити аргументе (Tugendhat, 1990, str. 22).

9 Овим је, такође, разбијено постојање свесног човека и постулирано човеково несвесно. У Духовној сийуацији времена Јасперс каже да је човек увек више него што зна да јесте (Jaspers, 1987, str. 114).

10 Психологија је тај проблем тематизовала обрађујући механизме одбране. 
Егзистенција је могућност човека који се појављује као постојање. Дакле, моје постојање није још нити је већ егзистенција, него је човек у йосйојању могућа егзистенција, каже Jacперс (Jaspers, 1987, str. 105). Егзистенција постоји само као слобода, она је слобода створена уз помоћ избора, а постоји само као могућност коју човек који филозофира схвата у егзистенцијалној одлуци. Досежући ту могућност, човек је слободан. Стога што слобода припада подручју егзистенције, питања о њој не могу ваљано да поставе емпиријске науке, нити се она може емпиријски истраживати. Она је ठивствовање човека који егзистира, а то ठивствовање за Јасперса није ништа друго до властито бивствовање, или ја са̂м.

Слобода коју човек има у тренуцима одлуке не значи ништа друго до то да човек постаје сама слобода. Властито бивствовање, избор и одлука чине целину, егзистенцијалну, изворну слободу. Зठог тога се и каже да бирајући јесам; ако нисам, не бирам (Jaspers, 1989, str. 374). То је разлог што Јасперс слободу означава као оно што је прво и последње у расветљавању егзистенције. Како човек има приступ унутрашњем свету? Том мишљу о слободи достигнутој одлуком добија се приступ унутарњем деловању. Моје питање о мени самом, о мојој слободи не произлази из свести уопште, већ из властитог ठивствовања. Како је у питању о слободи онај ко пита истовремено онај ко даје одговор, то је само питање чин - да ли и како себе досежем или напуштам. У том чину човек поставља питање о сопственом ठивствовању, и то је почетак самостварања у саморефлексији. То унушиарње gеловање је место на коме је заснован или ठи морао ठити заснован сваки облик психотерапије, а чија се филозофска суштина потпуно превиђа.

Саморефлексија је медијум тражења себе, али не на начин на који га схвата психологија. Не ради се о контемплативном, пасивном посматрању свога ја, већ о активном и на себе делујућем гледању властитог сопства. Прецизније речено, у егзистенцијалној саморефлексији, у којој се одвија расветљавање властитог бивствовања, човек тражи себе произлазећег из свог суда о себи. Окрећући се од ствари у свету ка себи, ја у саморефлексији испитујем свој чин, своје мотиве и осећања, према мерилу да ли јесам и хоћу да будем они сами (Jaspers, 1989, str. 293). Зато је за Јасперса саморефлексија унутрашње деловање, као што се може рећи да је унутрашње деловање саморефлексија и филозофирање. Вероватно се неће много погрешити ако се каже да саморефлексија, филозофирање и (егзистенцијална) психотерапија спадају у исти регистар, јер расвейљавају егзистенцију. 
Саморефлексија као питање, тражење, испитивање - није сврха, већ пут којим иде човек који тражи себе, каже Jacперс (Jaspers, 1989, str. 287). Тај пут који није самостудирање, већ комуникација са собом - води ка досезању могућности временског постојања. Стога се саморефлексија не остварује као сазнање, већ као самостварање (Jaspers, 1989, str. 287), јер се у њој тражи аутентично ठивствовање онога ко то бивство жели да досегне. Односити се према себи, каже Јасперс, не значи бити, већ значи ја сам, дакле, очекивати себе у унутрашњем деловању (Jaspers, 1989, str. 292). У том унутрашњем деловању се захтев „спознај самог себе” не остварује као нека когнитивна контемплација, него као самостварање сопства, јер се схвата заједно с другим захтевом: „постани оно што јеси".

Саморефлексија је услов за ступање у егзистенцијалну комуникацију без које човек не може бити прозиран самом себи, не може досећи остваривање сопства. Тек у егзистенцијалној комуникацији он се самом себи остварује помоћу другога. Оно што се збива у егзистенцији Јасперс назива сопством када се ради о узајамном стварању сопстава (Jaspers, 1989, str. 307). У том узајамном стварању човеку постаје приступачно бивство другог човека као и властито сопство. У остваривању, постојање губи свој карактер емпиријске постојаности, док човек стиче своје аутентично бивствовање као егзистенцију. Проблем је што постојање неретко истрајава против воље за остваривање властитог бивствовања и жели да остане затворено у својој таквости. У затворености постојање жели да сачува своје емпиријско ја, при чему одустаје од могућности своје егзистенције. У очигледности пак до које се долази само у комуникацији, превладава се то емпиријско ја и досеже се могућност егзистенције. Јасперс упозорава да појединац није за себе ни очигледан нити стваран (Jaspers, 1989, str. 288). Остваривање се не збива једноставним посматрањем. Само унутрашње делање у којем истовремено себе преображавам омогућује ми да се остварујем. Остваривање није никакав објективан догађај као сазнање природе, већ је као унутарње деловање самодосезање, самоизбор, присвајање (Jaspers 1987, str. 292).

Постављајући питање у конкретној ситуацији о свом ठивствовању, човек отвара границу на којој уочава своје аутентично $\delta$ ивствовање или пак своју неаутентичност због које пада у очајање. На тој граници, коју је створила рефлексија, човек спознаје да стоји пред избором: или остварење своје властите могућности, 
досезање свога сопственог сопства, или очајање да уопште буде. У том избору, који Јасперс назива егзистенцијалним, спознаје своју изворну, егзистенцијалну слободу у којој је основни поклич „ja бирам”. У таквом избору човек самога себе, својом егзистенцијалном савешћу, чини одговорним за своје делање у свету и за то што својом слободом ствара своје властито биће. У том избору човек спознаје да може одлучити о себи самом, о сопственом стварању. Зато што сам ја сам слобода тог избора, незамисливо је одвајање избора и ја, што је било блиско и самом Фројду, за кога није било сумње да бирајући јесам.

Егзистенцијалну одлуку посредује знање, мишљење и рефлексија ठез застоја. Но, погрешно би било мислити да по рефлексији следи одлука, јер је рефлексијом она тек у настанку (Jaspers, 1989, str. 356). Као апсолутни чин егзистенције, одлука је, како Јасперс каже, безусловна (Jaspers, 1989, str. 364) и спремна на одважност живота. Човек се одважује не да $\delta$ испунио пуку вољу постојања, већ да би досегао могућност егзистенције, да би остварио своју сопствену, непоновљиву и јединствену могућност. До тог остварења долази у великом тренутку одлуке. Егзистенцијална одлука је безусловно унутрашње деловање човека који филозофира, којим он досеже своју изворну слободу. Безусловно унутрашње деловање ${ }^{11}$ јесте корен сваке праве одлуке у спољном чину (Jaspers, 1989, str. 377). Одлука, која је врхунац унутарњег деловања, доводи до стварности могућност егзистенције. У психотерапији она следи само онда ако је субјект помакнут из средишта свести о себи ослобађањем говора. Психотерапија не може а да не препозна структуралне моменте хегеловске феноменологије: најпре дијалектику господара и роба, или дијалектику добре душе (belle âme) и закона срца, и уопште све оно што нам омогућује да схватимо како се изградња објекта подређује остварењу субјекта (Lacan, 1983, str. 76).

„Али ми се ठавимо робовима који мисле да су господари и који у језику, који има универзалну мисију, траже ослонац свом ропству и споне његове амбивалентности. А то чине у тој мери да би се са хумором могло рећи како је наш циљ да у њима поново успоставимо суверену слободу..." (Lacan 1983, str. 77).

11 То безусловно унушиарње gеловање и долажење-до-себе-самог јесте исто оно које Лакан тражи од пацијента када захтева да овај „не прави уступак на рачун своје жеље" (Lacan 1986, str. 17). 
Субјект је господар означитеља, макар и не ठио господар означеног у којем је његово биће задобило облик.

„Да би ослободили говор субјекта, увели смо га у језик његове жеље, то јест примарни језик у којем нам он, крај онога што нам казује о себи, већ говори а да не познаје себе, и то најпре у симболима симптома" (Lacan 1983, str. 78).

И егзистенцијалистичка психотерапија, (а неће се погрешити ако се каже) као и ठило која друга, јесте pag іовора (с пацијентом). Будући да се „историја” пацијента изражава у пољу говора, њен објект су ти ефекти значења - симптоми, снови, фантазми, илузије - које емпиричка психологија може разматрати једино као исечке понашања. Филозофија упозорава психологију, поготово психологију ठихевиоралне теорије, да изворе симболичког понашања не тражи изван подручја људског (у ракунима, голубовима или пацовима), како је добро уочио Жак Лакан (Lacan, 1983, str. 54). Конституишући човекову личност и његову судбину, jeзик је много више од практичног рецепта за комуницирање и изражавање идеја. Психологија не треба да посматра човека као ствараоца и господара језика, јер језик јесте и остаје човеков суверен, како су говорили Сартр, Хајдегер, Тугендхат, Лакан (Sartre 1979, str. 63).

Слика мишљења коју гради егзистенцијална психотерапија, која у свом општем стратегијском правцу јесте модел и за настојања других терапијских праваца који циљ постижу на други, мање или више сличан начин, јесте слика мишљења коју има филозофија. Не заборавимо да је већ у самом имену филозофије садржан појам љубави и тежње за знањем и спознајом, и да се на основи филозофије постиже душевни мир, који је израз знања о свету и животу. Егзистенцијална психотерапија, као и сви други облици терапије, и као психологија у целини - теже истом циљу.

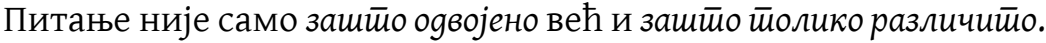

„Апстрактно објективизирање нашег искуства путем фиктивних начела, односно начела која подражавају експериментални метод: ту ми проналазимо дејство предрасуда од којих морамо очистити наше поље ако хоћемо да га обрађујемо према његовој аутентичној структури" (Lacan, 1983, str. 67).

То је тешко постићи ठез филозофије која нам може указати колико је и сам појам праве науке деградиран у 
„Позитивистичком преврату који је, постављајући друштвене науке у врх здања експерименталних наука, у ствари друштвене науке довео у подређен положај” (Lacan 1983, str. 67).

„Људи су бића која деле простор о коме физика ништа не зна.”

У томе се није тешко сложити с Петером Слотердијком (Sloterdijk 2010 , str. 83). На питање где борави субјект, који би требало да интересује психологију много више од личности, селфа или маске, психолошко истраживање би морало да да̂ одговоре који показују да оно што се види на физикалном плану, као и оно чиме се баве цивилне служठе - није ништа друго до лаж (Sloterdijk, 2010, str. 83). Снага и самосвојност знања којима располаже модерна психологија требало би да долази отуда што позицију човека измешта из домена геометрије и служби за пријаву боравка, како то не ठез цинизма каже Слотердијк (Sloterdijk, 2010, str. 83). Измештање позиције човека психологија ће обавити ваљано ако, полазећи од тога да је човекова природа свагда људска природа, за људску суштину узме оно што је још Спиноза узео: жељу. Жеља је срце људског постојања и централна преокупација психоанализе, али би требало да буде и централна преокупација психологије као науке о души у целини.

Проблем је у томе што егзактни смисао природњака у психологу - па и оном као што је Фројд - не допушта да филозофију прихвати као неку науку, иако децидирано каже да је оно што је тражио у медицини добио у филозофији. Филозофији се може приговорити да пружа беспрекорно повезану слику света, да прецењује сазнајну вредност логичких операција, да верује у интуицију као извор знања и да се одала анимистичким наклоностима јер верује у чаробно својство речи и утицај мишљења на стварност. Без речи, односно без мисли и њеног магичног носиоца - речи, тешко је замислити било које откриће. Али, није тешко сложити се с Томасом Маном да филозофија стварно стоји испред и изнад природних наука и да се сва методика и егзактност налазе у служби њене духовноисторијске воље. Идући до крајности, могло би се рећи да наука није никада дошла ни до каквог открића ако је филозофија није за њега ауторизовала или на њега упутила (Mann, 1952, str. 97). Данашња филозофија, како је говорио Јирген Хабермас, има задатак да у наукама подстакне јаке стратегије теорије наспрам емпиристичког елементаризма и индукционизма (Šarčević, 2010, str. 39). За психологију је то to be, or not to be. Дакако, с филозофијом, која се као и психологија бави 
„смислом $\delta и в с \overline{ш о в а њ а ” ~ и ~ п у т е в и м а ~ д а ~ с е ~ о н ~ о т к р и ј е ~ и л и ~ р а з у м е ~ у ~}$ начину на који човек обликује своју егзистенцију. И психологија и филозофија смисао бивствовања треба да траже у самом начину постојања људског бића. Филозофија нам указује да човек има посебан начин постојања, који Хајдегер назива „тубивствовање” (Dasein), који се не може објашњавайи као што се објашњавају предмети природних наука, већ га треба разумевайи на основу његових доживљаја и духовног стварања. Емпиријски елементаризам, о коме говори Хабермас, ту може бити од мале користи,

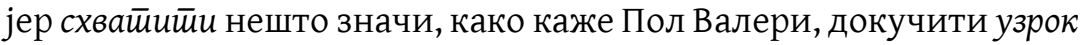
онога што човека покреће (Valéry, 2005, str. 80). Од тога пут иде ка разумевању могућности индивидуалног самоодређивања и самоостваривања, за које су филозофија и психологија подједнако заинтересоване и (са)одговорне.

Егзистенцијална психотерапија у којој је егзистенција схваћена као свесно, испуњено и ка бивствовању окренуто тубивствовање, Лаканово враћање Фројду уз исправљање самог Фројда несвесним које је структурирано као језик и Бионова филозофска ревизија Фројда уз помоћ Канта, тако се психички апарат дели на две менталне функције: функцију алфа, која одговара феномену и чува субјект од психотичног стања, и функцију $\delta e \bar{u} a$, која одговара ноумену (ствари по себи, идеји) и разголићује субјект, говоре најаргументованије о томе колико је блискост психологије и филозофије стварна добит за психологију.

ЛИТЕРАТУРА Aristotel(1971). Metafizika. Beograd: Kultura.

Arendt, H. (2013). Šta je filozofija egzistencije? Beograd: Dosije.

Bataille, G. (1995). Prokleti deo. Novi Sad: Svetovi.

Cioran, E. (2010). Razgovori. Beograd: Dereta.

Collins, J. \& Selina, H. (2005). Heidegger za početnike. Zagreb: Naklada Jesenski i Turk.

Davidson, D. (1995). Metafizički ogledi. Beograd: SIC.

Deleuze, G. \& Guattari, F. (1995). Šta je filozofija? Sremski Karlovci: Izdavačka knjižarnica Zorana Stojanovića.

Fink, B. (2009). Lakanovski subjekt. Zagreb: Kruzak.

Freud, S. (1970). Autobiografija. Zagreb: Zora.

Freud, S. (2003). Primedbe o jednom slučaju prisilne neuroze (Čovek pacov). Beograd: Čigoja štampa. 
Heidegger, M. (1985). Bitak i vrijeme. Zagreb: Naprijed.

Heidegger, M. (2006). Temeljni problemi fenomenologije. Zagreb: Demetra.

Jaspers, K. (1987). Duhovna situacija vremena. Novi Sad: Književna zajednica Novog Sada.

Jaspers, K. (1989). Filozofija. Sremski Karlovci: Izdavačka knjižnica Zorana Stojanovića.

Jaspers, K. (1978). Opšta psihopatologija. Beograd: Prosveta, Savremena administracija.

Kant, I. (1981). Zasnivanje metafizike morala. Beograd: BIGZ.

Lacan, J. (1974). „Nauka i istina”. U: M. Pervić (ed.), Marksizam-Strukturalizam (str. 101-123). Beograd: Nolit.

Lacan, J. (1986). „Etika psihoanalize”. Theoria 1-2, 9-25.

Lacan, J. (1988). The Ego in Freud's Theory and in the Technique of Psychoanalysis. New York: Norton.

Lacan, J. (1986). Četiri temeljna pojma psihoanalize. Zagreb: Naprijed.

Mann, T. (1952). Stvaraoci i dela. Novi Sad: Matica srpska.

Roudinessco, E. et Plon, M. (2002). Rečnik psihoanalize. Sremski Karlovci: Izdavačka knjižarnica Zorana Stojanovića.

Sartre, J.-P. (1979). Novi eseji. Beograd: Rad.

Sloterdijk, P. (2010). Sfere: mikrosferologija. Beograd: Fedon.

Šarčević, A. (2010). „Domašaji i granice Löwithove destukcije filozofije povijesti”. Dijalog, 3-4: 21-60.

Todorović, M. (2015). Psihoterapija. Beograd: Čigoja štampa.

Tugendhat, E. (1990). Jezičkoanalitička filozofija. Sarajevo: Veselin Masleša.

Valéry, P. (2005). Predavanja o poetici. Beograd: Karganović. 
MiLORAD V. TODOROVIĆ

UNIVERSITY OF PRIŠTINA WITH TEMPORARY HEAD-OFFICE

IN KOSOVSKa MITROVICA, FACULTY OF PHILOSOPHY

QUO VADIT PSYCHOLOGIA: A PHILOSOPHIA VEL AD PHILOSOPHIAM?

Where is psychology heading: away from philosophy or towards it? It seems that psychology itself had to thematize, inter alia, both scope and consequences of its "separation and individuation" from philosophy and its own philosophical origins. Instead of having a philosophical context, within which the previous psychological knowledge existed, the contemporary psychology has been left to metaphysics, meta-technique and mathematization for the purposes of its growth as an empirical science, extolling the scientific method conceived as a method of positive science, and loosing thus both its "soul" and the soul as a proper object of study. Its avoidance to use the word "soul" might be the best testimony thereof. Contemporary psychology - as an essentially anti-philosophical psychology - has placed the "psychological" in the physical, otorhinolaryngological or ophthalmological content, researching mostly only simple empirical relations. Such a psychology goes against its proper interests precisely because its anti-philosophical orientation reduces its research object to a physical fact prepared to enter exclusively mathematical operations. As opposed to that, a psychology maintaining its relationship with philosophy would itself be an experience, instead of being a mere theory. In place of psychology focusing on life itself, as Heidegger suggested, and not only on sensations, impressions based on touch, and memory factors, that what has been happening is exactly the opposite. If psychology was to examine life in its entire reality, it certainly wouldn't be forced to become the true philosophy, but the philosophical approach would only contribute to increased critical and comprehensive nature of psychological research. The manner in which the academic psychology perceives both individual functions and the subject himself provides a sound indicator of these "partial" objects of cognition. Those, in turn, as partial perspectives of psychological knowledge, inevitably lead to a multitude of psychologies. Only philosophy can represent the common denominator containing the need for creation of a unique science which does not imply the reduction of Multitude to One, but instead implies the forbearance of such theoretical 'outbursts' of prejudices against the concepts of "mental entities" and "psychic 
processes" that have characterized behaviorism. If Gilles Deleuze and Félix Guattari can pose a question about what philosophy is, then the psychologists could pose the same question. Especially since they could receive significant assistance from philosophy "as a skill of notion forming, inventing and production" (according to the teachings of Guattari and Deleuze, among others).

KEY WORDS: anti-philosophical psychology, existentialist philosophy, existentialist psychotherapy, sense of existence, divided subject, desire. 